TITLE:

\title{
Mosques in Japan responding to COVID-19 pandemic: Infection prevention and support provision
}

$\operatorname{AUTHOR}(\mathrm{S}):$

Kotani, Hitomu; Tamura, Mari; Nejima, Susumu

\section{CITATION:}

Kotani, Hitomu ... [et al]. Mosques in Japan responding to COVID-19 pandemic: Infection prevention and support provision. International Journal of Disaster Risk Reduction 2022, 69: 102702.

ISSUE DATE:

2022-02

URL:

http://hdl.handle.net/2433/266864

RIGHT:

(c) 2021 The Authors. Published by Elsevier Ltd.; This is an open access article under the Creative Commons Attribution 4.0 International license. 


\title{
Mosques in Japan responding to COVID-19 pandemic: Infection prevention and support provision
}

\author{
Hitomu Kotani ${ }^{\text {a, }}$, Mari Tamura ${ }^{\mathrm{b}}$, Susumu Nejima ${ }^{\mathrm{c}}$ \\ a Department of Urban Management, Graduate School of Engineering, Kyoto University, Kyoto, Japan \\ ${ }^{\mathrm{b}}$ Department of International Studies, Graduate School of Frontier Sciences, The University of Tokyo, Chiba, Japan \\ c Department of Regional Development Studies, Faculty of Global and Regional Studies, Toyo University, Tokyo, Japan
}

\section{A R T I C L E I N F O}

\section{Keywords:}

Islam

Muslim

Minority

Coronavirus

Religion

Faith-based organization

\begin{abstract}
A B S T R A C T
Religious activities tend to be conducted in enclosed, crowded, and close-contact settings, which have a high potential of transmitting the coronavirus disease, 2019 (COVID-19); therefore, religious communities are expected to take appropriate infection prevention measures. Meanwhile, during past disasters, religious communities have provided various types of support to affected people; hence, their role in disaster risk reduction has received much attention. In this study, we aimed to identify the infection prevention measures and support provision implemented by mosques-Islamic institutions managed and operated mainly by foreign Muslims living in Japan-during the one year from January 2020. We collected information from newspaper articles (18 articles on 19 mosques) and interviews with representatives of three mosques. We found that various infection control measures were implemented in mosques-refraining from mass prayers and closing buildings from an early stage (around February 2020); canceling large-scale events during the month of Ramadan; moving some activities online; and ensuring indoor ventilation and safe physical distance even when continuing face-to-face prayer activities. We also found that various types of support were provided by mosques-donating masks to the local government; listening to problems of people affected by COVID-19 regardless of their nationality; providing financial support to them; translating and disseminating information to foreign Muslims; and providing religious meals for them. This study provides actual examples of infection prevention measures taken by mosques in a Muslim-minority society and suggests that mosques appropriately responded to the needs of religious minorities during disasters, including COVID19.
\end{abstract}

\section{Introduction}

The coronavirus disease 2019 (COVID-19), being a biological hazard [1] and a slow-onset disaster [2], has had a profound impact on religious communities. COVID-19 is more likely to spread through droplets [3] and in environments known as the "three Cs" (confined and enclosed spaces with poor ventilation; crowded places with many people nearby; and close-contact settings, such as close-range conversations) [4]. As a large number of people gather in religious facilities to worship and preach, there is an increased risk of the disease spreading. In fact, several cases of religious activities being the source of infection have been reported worldwide-congregations and activities related to Islam (Tablighi Jamaat) in Malaysia, Pakistan, and India; Christianity in South Korea and

\footnotetext{
* Corresponding author.

E-mail addresses: kotani.hitomu.5c@kyoto-u.ac.jp (H. Kotani), tamura.mari.19@dois.k.u-tokyo.ac.jp (M. Tamura), nejima@toyo.jp (S. Nejima).
} 
the Netherlands; Judaism in Israel; and Sikhism in India, contributed to the spread of COVID-19 in the corresponding as well as neighboring countries [5-8]. To prevent the spread of infection, religious communities were required to reassess their activities, canceling events and replacing worship with online services [9].

Meanwhile, there are several examples of religious communities reaching out to people affected by disasters that relate to natural hazards $^{1}$ [10-17]. Hence, these communities are expected to play a significant role in disaster risk reduction $[10,13,17,18]$. During the COVID-19 outbreak as well, religious communities are expected to share health information to protect their own members and wider communities [3]. Therefore, an understanding of the support provided by religious communities to those affected by COVID-19 will increase an understanding of their role during disasters and may provide useful information for governments and other stakeholders to collaborate with them in the future.

Religious communities in Japan were also affected by COVID-19. After the first domestic positive case was confirmed in January 2020, the number of positive cases increased in February and March. The government declared a state of emergency in April; however, it was not a strict lockdown with restrictions on people's activities, but only a "request" to refrain from going out, to cancel or postpone large-scale events, and to close offices. Even after the state of emergency was lifted, the government did not enforce any restrictions on the number of people attending events. In such a situation where voluntary actions of people were required, several studies reported infection prevention measures taken by religious communities and organizations, including those of Buddhism, Shintoism, and new religions ${ }^{2}[19,20]$, which are the major religions in Japan. In contrast, there are almost no studies on organizations belonging to minority religions, especially those that are managed mainly by foreigners. Mosques (called masjid in Arabic) have been established in various parts of Japan and are mainly managed and operated by foreign Muslims ${ }^{3}$ living in Japan. Many Muslims gather in mosques for religious practices, but it is unclear what measures the mosques have taken to prevent the spread of COVID-19.

Furthermore, foreigners tend to be more vulnerable to disasters due to their religious, cultural, and linguistic differences [21,22]. During past disasters in Japan, mosques have provided support not only to Japanese but also to minority foreigners [23-25]. However, it is not clear what support mosques provided to Japanese and foreign residents during the COVID-19 pandemic.

This study, therefore, aims to identify (1) the infection prevention measures taken by mosques in Japan to cope with COVID-19 and (2) the support they provided to Japanese and foreign residents. To achieve this purpose, we collected qualitative information from relevant articles in major Japanese newspapers and conducted interviews with mosque representatives, targeting the period until the end of 2020 .

The rest of the paper is organized as follows: to contextualize the study, Section 2 overviews mosques in Japan and their responses to past disasters. It also summarizes the timeline of the expansion of COVID-19 and the government's response in Japan; Section 3 presents the details of the newspaper article collection and the interview surveys; Section 4 demonstrates the results obtained from the analysis of the newspaper articles and interviews; Section 5 discusses the results; and Section 6 concludes the study and describes future work.

\section{Background}

\subsection{Mosques in Japan}

The population of Muslims in Japan is seeing an upward trend; however, Muslims by far are the minority in Japan's total population of approximately 120 million, including foreigners [26,27]. A large proportion of the Muslims are thought to be foreigners living in Japan, with past studies estimating the foreign Muslim population to be about 59,000 in 2004 [28], 100,000 in 2010 [29], and 157, 000 (equivalent to $79 \%$ of all Muslims) in 2018 [30]. The top countries of origin are mainly in Southeast Asia and South Asia, such as Indonesia, Pakistan, the Philippines, Bangladesh, Malaysia, Turkey, and Iran as of 2018 [30].

The history of mosque construction in Japan begins with the Kobe Muslim Mosque in 1935 [29]. With the economic boom after the 1980s, there was a massive influx of Muslims as foreign workers. Subsequently, an increasing number of mosques have been built since the 1990s. There existed 80 mosques in 2014 [29], which increased to 96 in 2017, and if those under construction are included, the number reaches 100 [31], and continues to grow. Some mosques have heads of facility management (referred to as amir) or leaders who manage congregational prayers (imam) and are responsible for the operation and management of the mosques. Other mosques utilize the corporate system (i.e., religious or general incorporation) and the responsible officers play a central role in the operation. Many of such managers and administrators are foreigners.

The five daily prayers may be performed at home or work, but Friday collective prayers are recommended to be performed at mosques. Many mosques also hold collective prayers on Saturday to follow the Japanese society [29]. Hence, mosques are places where many Muslims gather on Friday and Saturday. Study sessions focusing on Qur'an recitation and its interpretation are held mainly after Friday and Saturday prayers. The availability of such education for women and children varies across mosques, whereas that for adult men is ensured in most mosques [29].

\footnotetext{
1 There is no such thing as a natural disaster since all human activities that precede and follow the natural hazards are contributing factors if not the main reasons for the hazards to become a disaster [77,78].

${ }^{2}$ Organizations labeled as "new religions" in Japan are the ones founded in the last two centuries that are institutionally and categorically distinct from older sects [19]. Examples of new religions include Tenrikyo and Rissshō Kōsei Kai.

${ }^{3}$ In this study, foreign Muslims refer to Muslims with foreign citizenship, who are a majority in Japan's Muslim population, as shown in Section 2.1. Meanwhile, there are Muslims with Japanese citizenship, often categorized in two groups [27]: (1) people, mainly men, who converted to Islam, for example, through the study of Islam or Arabic and (2) people, generally women, who converted to Islam by getting married to foreign Muslims and children from these marriages (referred to as "born Muslims"). Their roles might be different from those of foreign Muslims in mosques and are worth exploring in detail in the future.
} 


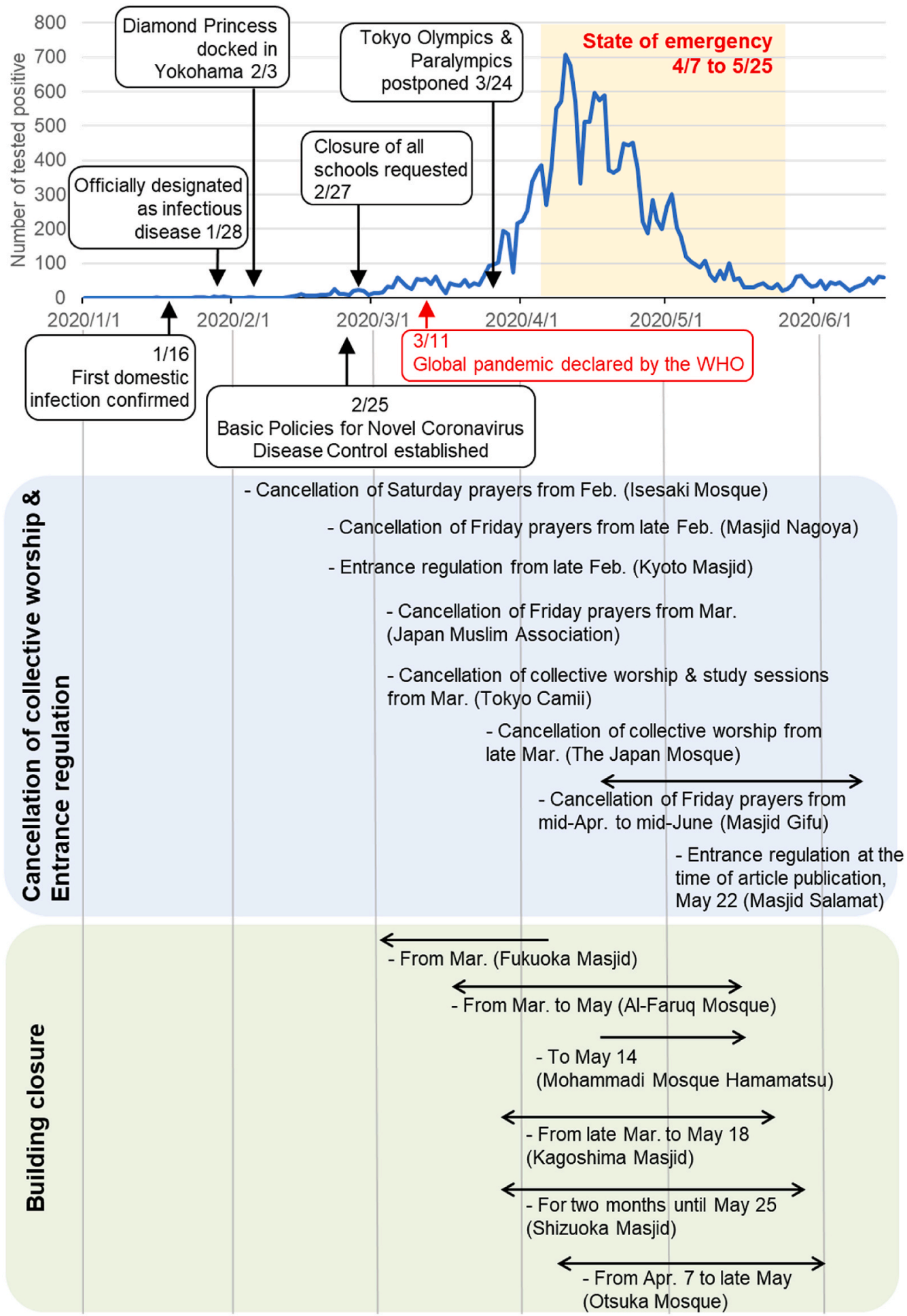

Fig. 1. Timeline of infection status, cancelation of worship, and closure of mosques in Japan.

In addition to the above-mentioned regular activities, during the month of Ramadan, many important religious practices are performed. Muslims fast from dawn to sunset following one of the five pillars (religious duties) of Islam. In 2020, the month of Ramadan corresponded to April 24-May 23. Usually, many Muslims visit mosques in the evening and break the fast together with light meals, such as dates. After the evening prayer, they have the main meal in the mosque. This is called the iftar party. Some Muslims 
remain at the mosque for reciting Qur'an and night prayers. Iftar meals are served for free since wealthy Muslims pay for the cost. In fact, Ramadan is known as the month of charity, and many Muslims pay zakat (another one of the five pillars, or almsgiving) and zakat al-Fitr, which is a small charity for the poor to prepare Eid al-Fitr. Eid al-Fitr is the festival of breaking the fast (in 2020, it was held on May 24), in which people who do not usually visit mosques also show up to pray [29,32].

In Muslim-majority countries, mosques are facilities primarily for worship, while they also perform important and diverse functions in the lives of Muslims; this is also true in Japan, which is a Muslim-minority country [29].

\subsection{Role of mosques in Japan during past disasters}

When disasters struck Japan in the past, mosques provided support and relief goods to affected Muslim foreigners and other nonMuslims. For example, after the Kobe earthquake in 1995, Kobe Muslim Mosque was used as a shelter for affected Muslims for several months $[23,24]$. Soon after the earthquake, halal food was sent from embassies, Islamic groups, and individuals across Japan to the mosque, with no worry of running out of food during the evacuation [24]. During the 2011 Tohoku earthquake and tsunami, Sendai Masjid (Islamic Cultural Center of Sendai), located in the Tohoku region, received a large number of relief goods from Muslims living all over Japan. Sendai Masjid also served as a host for volunteers from distant mosques and took them to coastal shelters and provided relief supplies to the victims, including non-Muslims [33]. Otsuka Mosque, which was located in Tokyo, far from the Tohoku region, delivered food and relief supplies to the affected areas immediately after the disaster, and also served food at evacuation shelters. The number of such activities at shelters reached more than 80 in six months after the disaster [34]. During the 2016 Kumamoto earthquake, Kumamoto Masjid (Kumamoto Islamic Center) provided supplies, food, and information in foreign languages to foreigners in the affected areas [25]. These examples indicate that mosques, which are generally managed by foreigners, have the potential to approach foreign victims, including Muslims, who tend to be vulnerable in times of disasters, as well as Japanese people, since they share similar social backgrounds and customs and common languages.

\subsection{Timeline of virus prevalence and state response in Japan in 2020}

The upper part of Fig. 1 summarizes the number of COVID-19 positive cases in Japan and related government actions until midJune 2020. On January 16, 2020, the first COVID-19 case, with the case-patient having a travel history to Wuhan, China, was reported in Japan [35], and subsequently, other COVID-19 cases without travel history to Wuhan within the last 14 days, were reported on January 28. On that same day, Japanese Prime Minister announced COVID-19 as an infectious disease under the Infectious Diseases Control Law [36]. A COVID-19 headquarters was established on January 30. The luxury cruise ship Diamond Princess docked in the Yokohama Port on February 3 [37,38]. A large number of passengers onboard testing positive for COVID-19 drew both national and international attention. On February 25, the fundamental plan of action (Basic Policies for Novel Coronavirus Disease Control) was introduced by the Government [39]. On February 27, the Prime Minister requested the closure of all schools from March 2 until the spring vacation [40]. However, the decision of whether to close schools was up to the school administrators and local governors. On March 11, the World Health Organization (WHO) declared COVID-19 a global pandemic [41]. On March 24, the postponement of the Tokyo 2020 Olympics and Paralympics was announced [42].

The number of positive cases increased rapidly from the end of March, and consequently, on April 7, Prime Minister declared a state of emergency in seven prefectures, including Tokyo, which was expanded to the entire nation (i.e., other 40 prefectures) on April 16 [43-46]. The governors of the targeted prefectures requested residents to refrain from going out except when necessary, and asked managers of facilities where many people gather, such as department stores and movie theaters, to restrict their use. It should be noted that these instructions were only "requests," not orders. From mid-April, the number of positive cases was on the decline; the state of emergency was therefore lifted in 39 prefectures on May 14 and finally, in all prefectures on May 25. As of the latter half of April, about $90 \%$ of public schools (kindergartens and elementary, middle, and high schools) across the country had remained closed [47], but after the state of emergency was lifted, they gradually opened, and the situation was largely normalized in June. For further details of this first wave of infection and state responses, see Tashiro and Shaw [48] and Shimizu and Negita [49].

In late July, Japan launched a domestic tourism campaign (Go To Travel campaign) that encouraged people to travel freely throughout the country to revitalize the moribund tourism industry [50]. During the same period, from the latter half of July to the first half of August, Japan was struck by a second wave of positive cases (a maximum of 1595 people-day tested positive). While this time the government did not declare a state of emergency, the number of positive cases started declining from September (around 500 people/day). However, from November to the time of writing this paper (January 2021), the number of positive cases has been on the rise again (considered to be the third wave). Consequently, the Go To Travel campaign was suspended in some municipalities in the latter half of November; it has been suspended, nationwide, since December 28 [51].

\section{Methods and materials}

The target period of this study is approximately one year from January 2020, when the first COVID-19 positive cases were identified in Japan. To obtain broad and detailed information, we collected newspaper articles on mosques and conducted interviews with representatives of mosques.

\subsection{Newspaper article collection}

We collected newspaper articles from the online databases of the four major newspapers in Japan (Asahi Shimbun, Mainichi Shimbun, Yomiuri Shimbun, and Nihon Keizai Shimbun; all of which are in Japanese) until the end of 2020, using "corona" and either "mosque," "Islam," or "Muslim" as search keywords in Japanese. Simultaneously, we checked the contents of the articles for whether 
they were related to infection prevention measures taken by mosques and the support provided by them during the COVID-19 pandemic. As a result, 18 articles on 19 mosques were collected, with the majority of them presenting information up to the end of June (i.e., almost one month after the end of the state of emergency). ${ }^{4}$

\subsection{Interview surveys}

For the interview survey, we selected a mosque from each of the central areas, where the COVID-19 expansion was significant, the surrounding areas, and the distant areas: (1) Otsuka Mosque in Tokyo, (2) Sakaimachi Mosque in Gunma Prefecture, and (3) Al-Faruq Mosque in Toyama Prefecture (Fig. 2 and Fig. 3). Each mosque was operated by either a religious or a general corporation. ${ }^{5}$ The semistructured interview surveys were conducted between November 2020 and January 2021, either online or face-to-face with one representative from each mosque, in Japanese (Table 1). Before the survey, they were informed of its purpose, and all of them consented to participate. We asked questions about regular prayers and religious events held during the COVID-19 pandemic, infection prevention measures that have been implemented in the mosques, the use of internet, and the support provided, if any. The duration of interviews was approximately 60, 60, and $105 \mathrm{~min}$ for Otsuka, Sakaimachi, and Al-Faruq Mosques, respectively.

\section{Results}

\subsection{Summary of newspaper articles}

Based on the newspaper articles, we summarized when and how each mosque imposed restrictions on prayer activities and building use to prevent COVID-19 (the lower part of Fig. 1). In the early stages of the outbreak, that is, February and March 2020, some mosques decided to cancel activities such as Friday and Saturday prayers and Qur'an study classes and restrict entry to buildings (e.g., Isesaki Mosque, Masjid Nagoya, Kyoto Masjid). From March, other mosques started to close their buildings (e.g., Fukuoka Masjid Al Nour Islamic Culture Center, Al-Faruq Mosque). Many remained closed until around the end of May. Some mosques were closed for the first time since their opening (Kagoshima Masjid [52]; Al-Faruq Mosque [53]; Masjid Nagoya [54]).

In the month of Ramadan, which fell during the period of the state of emergency, special prayers and iftar were canceled in many mosques (there were reports on 12 mosques). According to the Mainichi Shimbun [55], in mid-April, before Ramadan, 40 mosques and Islamic organizations in the country, as well as 50 Islamic scholars, met online to discuss COVID-19. They called for avoiding mass gatherings and practicing prayers and iftar at home in response to the declaration of the state of emergency. There is high likelihood that this meeting refrained many mosques from holding activities during Ramadan.

Infection prevention measures were taken even when prayer activities were continued (Table 2). For example, even during the state of emergency (April-May), some mosques (i.e., Kobe Muslim Mosque and Kumamoto Masjid) did not close their buildings and continued worship activities, taking measures, such as calling for self-refrain from participation by believers who were not feeling well; encouraging participation by a small number of people; and ensuring washing hands, physical distancing, and indoor ventilation. After the state of emergency was lifted (i.e., from the end of May), there was a tendency to resume Friday prayers and regular prayers wherein measures, such as wearing masks, hand disinfection, ventilation, and maintaining physical distance, were taken. Some mosques took measures with the support of the government-public health nurses visited mosques and instructed management staff and leaders of the mosque on how to properly wear masks and wash hands (Ebina Masjid) [56]. As of December 2020, however, some mosques were still refraining from Friday prayers (Osaka Masjid) [57], and appeared to be reluctant to resume collective prayers. The use of online services has been observed in some mosques-a chief missionary delivered daily sermons via a video streaming service when the mosque was closed (The Japan Mosque) [54], and some study sessions for children were switched to video calls (Isesaki Mosque) [58].

Some mosques provided support for believers. Kobe Muslim Mosque provided counseling for believers who lost their jobs or were unable to return to their home countries due to the spread of COVID-19 [59]. The Japan Mosque translated information from the local government for believers who had limited Japanese proficiency and provided counseling on daily life issues [54]. During Ramadan, Kumamoto Masjid supplied food for believers. More specifically, some Muslim international students were worried about their financial situation because their part-time jobs had to shorten their business hours due to the COVID-19 pandemic. Iftar at the mosque is valuable for students with financial constraints. Therefore, as it was canceled, the mosque was concerned about the students and provided them with free lunch boxes [55]. Similarly, Shizuoka Masjid, after it decided to cancel iftar, set up a food box in front of the building to provide food for those who were struggling to prepare meals [66].

\subsection{Summary of interview surveys}

\subsubsection{Otsuka Mosque}

Otsuka Mosque continued its prayers, ensuring physical distance between believers, until the declaration of the state of emergency. However, during the state of emergency (April 7-May 30, 2020), the building was completely closed after consultation with the local government and police. During the closure, only the believers living in the mosque continued to pray at the mosque. After the state of emergency was lifted (after June 1), the mosque was reopened for use. Friday prayers were divided into three sessions and sermons

\footnotetext{
${ }^{4}$ Of the 18 articles, nine were from the Asahi Shimbun [52-54,58,63,65,66,79,80], five from the Mainichi Shimbun [55,57,61,62,81], and four from the Yomiuri Shimbun [56,59,60,64]. There was no article from the Nihon Keizai Shimbun. Based on the publication month, two articles were published in April; 10 in May; two in June; one in July; one in November; and two in December.

5 Otsuka Mosque was operated by the Japan Islamic Trust, Sakaimachi Mosque by Darussalam, and Al-Faruq Mosque by the Toyama Muslim Center.
} 
were shortened; regular prayers five times a day attracted about 10-20 people, which was not very different from the number in previous years. Before the COVID-19 pandemic, the Qur'an study session on Saturday and the dinner party afterward (both of which attracted about 100 people) were held, but these activities were suspended in the wake of the pandemic. Furthermore, before the outbreak, there was a study session for women that attracted about 10-50 people, but it started to be held virtually around February and March 2020. During Ramadan, special prayers and iftar were also canceled. The domestic online meeting mentioned in Section 4.1 was organized mainly by Otsuka Mosque.

In addition to the above, various prevention measures against COVID-19 were taken after the resumption of prayer activities. A new hand-washing area was set up outside the mosque to ensure that believers washed hands before entering the mosque. Hand sanitizers were also installed. Believers were requested to wear masks, and those who did not bring their masks were provided one at the entrance. The worship room was small (60-65 square meters); therefore, the doors and windows were kept open for ventilation during worship. Posters were also displayed to raise awareness about prevention.

The mosque also provided support to foreigners and Japanese people suffering from the pandemic. Even before the pandemic, the mosque (i.e., the director, managers, and believers) had been providing support for the homeless and conducted counseling for Japanese and foreigners on daily life issues, as well as made donations to those with financial problems. With COVID-19, there was an increase in the number of consultations related to hardships in life. The mosque also provided believers with information released by the government, posting it in Japanese and English at the mosque.

\subsubsection{Sakaimachi Mosque}

Sakaimachi Mosque did not close its building during the state of emergency. However, it did not hold special Ramadan prayers and iftar (which usually attracted about 300 people) and continued only small-scale activities. Around May and June 2020, since there were many positive cases in Gunma Prefecture, the weekday, Friday, and Saturday prayers were held several times around the regular time of the service. The mosque also encouraged people to hold worship services in small groups at their homes or friends' homes. Since around August 2020, the mosque has held regular services and Friday services with the same number of people as usual (approximately 20 and 200, respectively). On Saturday, the sermon after the service has been shortened to about half of its original duration of $40 \mathrm{~min}$. Before the COVID-19 outbreak, the mosque used to hold a dinner party after Saturday prayers, but it was suspended, and there were no plans to resume it at the time of the survey. According to the interviewee, the number of people attending the Saturday prayers was lower than usual (around 200-300 people), probably because of the shortened sermons and the cancelation of the dinner party.

The mosque also implemented various prevention measures against COVID-19. Hand sanitizer was placed at the entrance of the mosque (Fig. 4 (a)). Wearing masks was encouraged and posters to raise awareness of prevention were displayed at the entrance of (Fig. 4 (b)) and inside (Fig. 4 (c)) the mosque. Some posters were created by the representative (i.e., interviewee). Ventilating fans, a humidifier, and an air purifier were used. It is normally desirable for people to pray shoulder-to-shoulder with persons praying next to them (Fig. 4 (d)); however, during the pandemic, people were encouraged to maintain safe physical distance (Fig. 4 (e)). After each service, an antiseptic solution was sprayed on the carpet touched with hands and faces (Fig. 4 (f)). The mosque also received assistance from external organizations-e.g., city officers visited the mosque and spread awareness on infection prevention measures through leaflets and e-mails. Darussalam, a religious corporation, which operated Sakaimachi Mosque, requested the mosque to follow the guidelines from the city and prefectural governments. ${ }^{6}$

The mosque actively provided information to the believers. Before the pandemic, there was no online group, but one was created in April 2020. In the online group, the mosque not only informed the believers of the schedule of activities in advance because of the irregularity of prayers, but also provided information about infection situation in the prefecture by translating it into Urdu and Bengali.

\subsubsection{Al-Faruq Mosque}

Al-Faruq Mosque was closed during the state of emergency. Around May, with the guidance of the local government and taking infection prevention measures, the mosque resumed prayer activities. To avoid congestion in the small prayer space, the elderly and children were requested to refrain from coming to the mosque. During worship, the mosque opened the windows for ventilation and requested the believers to use hand sanitizer, wear masks, and maintain physical distance. Prayers, which normally had taken about 30 min, were reduced to about 5 min to shorten the stay of believers.

The mosque provided support to the local government. The mosque representative (i.e., interviewee) had worked in Russia before coming to Japan, and based on this connection, the mosque procured 2000 masks from Russia and donated them to the city office in May. The donation was mentioned on the city office website [67].

\section{Discussion}

In Japan, no strict restrictions were placed on people's activities even during the spread of COVID-19. In such a situation, what infection prevention measures were implemented by mosques, which were managed mainly by foreign Muslims? What support was provided by mosques for Japanese and foreign residents? To answer these questions, this study collected information until December 2020 from newspaper articles and interviews with representatives of three mosques.

\footnotetext{
${ }^{6}$ According to Okai [31], Darussalam operated 18 other mosques, and Japan Islamic Trust, which operated Otsuka Mosque, managed three other mosques around Japan. While we conjecture that each mosque responded to the crisis following its own criteria, it may be interesting to determine how mosques in the same religious corporations responded to the pandemic. Future work should explore mosques as players in inter-mosque networks in detail.
} 


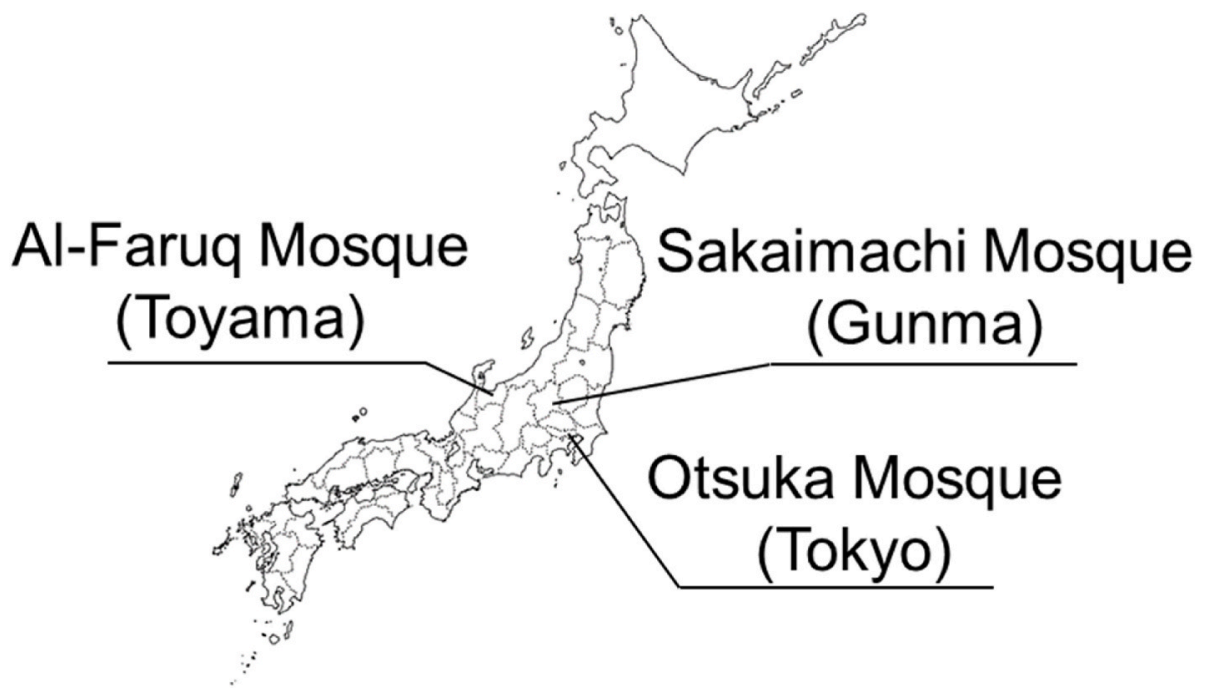

Fig. 2. Location of the targeted mosques.

\subsection{Measures to prevent religious community transmission}

Based on the results from the analysis of newspaper articles and interviews, the overview of mosques' responses to COVID-19 until the end of 2020 is presented in Fig. 5. In February and March 2020, before the state of emergency was declared, some mosques decided to cancel Friday and Saturday prayers and closed their buildings (Fig. 1). Similar to other religions in Japan, for example, the Soka Gakkai, a new Buddhist movement that took immediate measures, closing its headquarters in mid-February and reducing face-to-face contact [19], and a Christian church that canceled mass, weekly prayers, and other activities at the end of February [20], some of the mosques also responded speedily to the situation. As Ramadan came during the period of the state of emergency in Japan, many mosques autonomously canceled most of the special prayers and events, which must have been important to believers, through the collective decision-making process of the online meeting, which brought together 40 mosques and Islamic groups.

So far, McLaughlin [19] is the only study on online services provided by the Islamic organizations during the pandemic, reporting that the Tokyo Camii and Turkish Culture Center, a mosque and Muslim education center, switched to Zoom for all its congregational prayers, classes, and Ramadan events. The current study adds to this knowledge by providing examples of other services, such as online lectures on Islam (Isesaki Mosque in Section 4.1), uploaded videos of sermons (The Japan Mosque in Section 4.1), and online study sessions (Otsuka Mosque in Section 4.2.1). Other religions in Japan were also reported to have substituted physical activities with online events and prayers, for example, Facebook-based online sutra reading by temples, video-on-demand learning about teaching by the Soka Gakkai [19], and the use of Zoom by Christian churches for online performance of mass and sermons [20]. The results of this study reinforce the claim that Islam, like other religions, switched to the online medium for some of its activities.

While many mosques closed their buildings during the state of emergency (Fig. 1), some continued to conduct face-to-face smallscale activities during this period (e.g., Kobe Muslim Mosque in Section 4.1 and Sakaimachi Mosque in Section 4.2.2). After the state of emergency was lifted, face-to-face worship activities were resumed. These religious activities were conducted with various infection prevention measures in place. To prevent infection during worship services, WHO [3] recommends indoor ventilation, safe physical distancing, multiple prayers with few attendees, washing hands before and after prayers, disinfection of worship rooms, and so forth. Many of these measures were implemented in the mosques. Therefore, it can be said that mosques took appropriate prevention measures against COVID-19 and conducted religious activities with due care for infection prevention.

Most Japanese are unfamiliar with Islam [27]; thus, it is difficult for them to know what infection control measures were implemented in mosques in Japan. Disinformation polarizes public debate on topics related to COVID-19, amplifying hate speech, heightening the risk of conflict, violence, and human rights violations, and threatening long-term prospects for advancing democracy, human rights, and social cohesion [68]. The above findings will help people understand unfamiliar Islamic groups correctly and contribute to the realization of a multicultural society.

Our findings also complement the international picture of the responses of Muslims to the pandemic. The responses in Muslimmajority countries, which differed from country to country, are well known-for example, the Kingdom of Saudi Arabia took the unprecedented step of temporarily closing 80,000 mosques and suspending the daily and Friday prayers and the Two Holy Mosques in Makkah and Medina were also temporally closed for the public [69], while the government in Pakistan allowed mosques to open for daily five-time congregational prayers during Ramadan [70]. This study focuses on a Muslim-minority country and discusses the measures taken by different mosques in detail, filling the gap concerning how Muslims responded to the pandemic globally.

\subsection{Support provision for non-muslims and muslims}

The support provided by mosques during the pandemic can be summarized as shown in Table 3. For example, there were donations of masks to the local government (Al-Faruq Mosque in Section 4.2.3) and counseling services and financial support for non-Muslim 
(a)

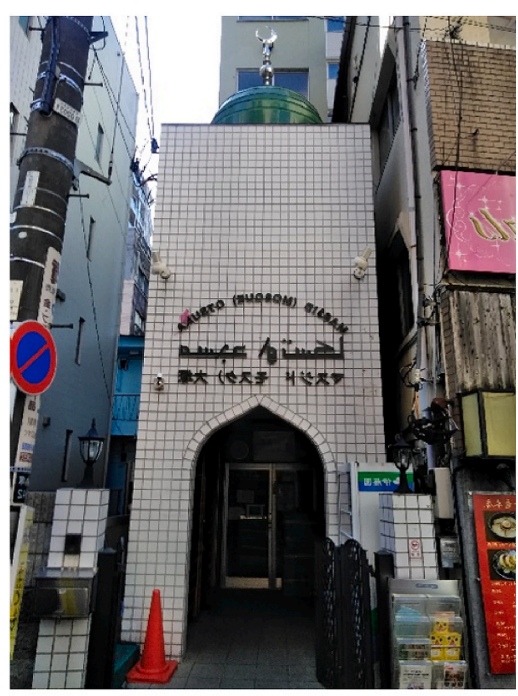

(b)

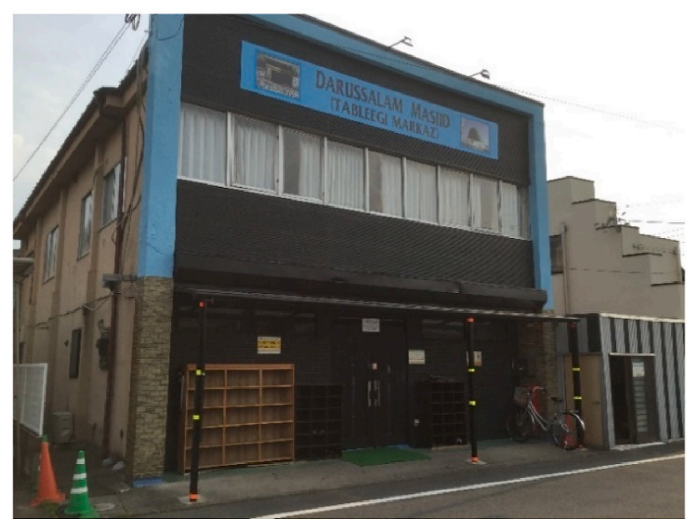

(c)

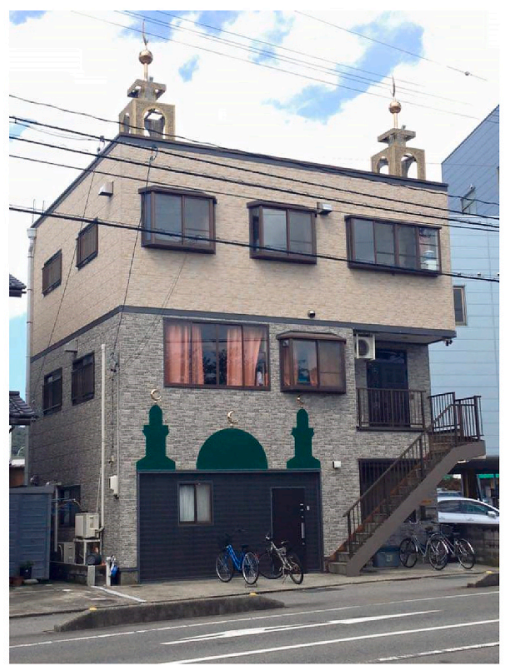

Fig. 3. (a) Otsuka Mosque; (b) Sakaimachi Mosque; (c) Al-Faruq Mosque.

Japanese (Otsuka Mosque in Section 4.2.1).

Some mosques provided support to foreigners. They provided counseling services for believers who had lost their jobs or were unable to return to their home countries (Kobe Muslim Mosque in Section 4.1) and translated information from the local government for believers with limited Japanese proficiency (The Japan Mosque in Section 4.1). According to Cavaliere [20], Christian churches provided a wide range of helpdesk information, from contacts and procedures in case of COVID-19 infection to legal consultation about

Table 1

Details of interview surveys.

\begin{tabular}{|c|c|c|c|}
\hline Name of mosque (Organization) & Date & Interviewee (Nationality) & Methods \\
\hline $\begin{array}{l}\text { Otsuka Mosque } \\
\text { (Japan Islamic Trust) }\end{array}$ & January 6, 2021 & $\begin{array}{l}\text { Executive director } \\
\text { (Pakistani) }\end{array}$ & Online interview \\
\hline $\begin{array}{l}\text { Sakaimachi Mosque } \\
\text { (Darussalam) }\end{array}$ & November 24, 2020 & $\begin{array}{l}\text { Imam } \\
\text { (Bangladeshi) }\end{array}$ & Face-to-face interview \& field observation \\
\hline $\begin{array}{l}\text { Al-Faruq Mosque } \\
\quad \text { (Toyama Muslim Center) }\end{array}$ & December 16, 2020 & $\begin{array}{l}\text { Chief director } \\
\text { (Dual nationality: Syrian \& Russian) }\end{array}$ & Online interview \\
\hline
\end{tabular}


visas due to COVID-19 related restrictions. Like churches, mosques are considered to have contributed to solving problems that were common to general foreigners.

Other mosques provided support in reducing problems specific to Muslims. They delivered free lunch boxes (Kumamoto Masjid in Section 4.1) and set up food boxes (Shizuoka Masjid in Section 4.1), being concerned for those who relied on iftar. Among the issues related to foreigners, such problems faced by the religious minority are considered hard to understand by other stakeholders, including the government. Mosques' responses to these problems could meet the needs of foreign Muslims, which strengthen their mental and spiritual health and well-being [3]. During disasters related to natural hazards, mosques have been helpful to both non-Muslim communities [25,33,34] and Muslim communities [23,24,33]; this study has shown the detailed support that mosques provided for each community during the COVID-19 pandemic.

Amid the COVID-19 crisis, it is important to deliver services and information from health care providers and the government to foreign residents in Japan who have such needs, and stakeholders who act as a bridge between them are urgently required [71]. To "leave no one behind"- the slogan of the sustainable development goals (SDGs) [72] —and multi-stakeholder partnership to achieve this goal (i.e., SDG 17) are also internationally demanded. Our results suggest that mosques can have a high potential to serve as such a bridge. That is, through collaboration with mosques, the government sector may be able to improve access to foreigners, especially foreign Muslims, and properly identify their needs. Some government stakeholders already have contact with mosques (i.e., Ebina Masjid in Section 4.1 and Sakaimachi Mosque in Section 4.2.2), and it is hoped that these collaborations will be further deepened and applied to other areas. Preparing for natural hazard-related disasters, an increasing number of local governments in Japan have formed disaster relief agreements with religious institutions and organizations of major religions, that is, Buddhism and Shintoism [73]. Our findings will help local governments comprehend minority religious institutions, that is, mosques, and may facilitate their collaboration in times of disasters.

\section{Conclusion}

The purpose of this study was to identify the measures taken by mosques in Japan to prevent the spread of COVID-19 and the support provided by them to Japanese and foreign residents during approximately the one year after the first domestic positive case was confirmed, in January 2020. For this purpose, we collected secondary information from newspaper articles and primary information from representatives of three mosques. We found that the mosques took various prevention measures, such as refraining from mass prayers and closing buildings from an early stage of the pandemic, canceling large-scale events during Ramadan, and shifting to the online medium, as well as ensuring indoor ventilation and safe physical distance when continuing face-to-face prayer activities (Fig. 5). Furthermore, as seen in the case of past disasters, mosques provided support to the people affected by COVID-19, regardless of their nationality, especially to Muslims (Table 3). In other words, mosques appropriately responded to the unique needs of Muslims living in Japan, which would be difficult for other stakeholders to address. The above measures taken by mosques, which are unfamiliar to many Japanese, can compensate for the lack of information about mosques and contribute to deterring infodemics related to COVID-19. The examples of support provided by mosques suggest that mosques can play a role in bridging the gap between foreign

Table 2

Infection prevention measures taken by each mosque.

\begin{tabular}{|c|c|c|c|}
\hline Name of mosque & $\begin{array}{l}\text { Date of article } \\
\text { (in 2020) }\end{array}$ & Description & Source \\
\hline Kobe Muslim Mosque & April 13 & $\begin{array}{l}\text { The windows of the prayer hall (approx. } 100 \text { square meters) were } \\
\text { opened for ventilation, and believers who were not feeling well were } \\
\text { requested not to visit. }\end{array}$ & [59] \\
\hline Kumamoto Masjid (Kumamoto Islamic Center) & May 12 & $\begin{array}{l}\text { Except for large gatherings such as Friday prayers and iftar, small-scale } \\
\text { activities were allowed in the building with disinfection and safe } \\
\text { physical distancing. }\end{array}$ & [55] \\
\hline Masjid Salamat & $\begin{array}{l}\text { May } 12, \\
\text { May } 22, \& \\
\text { June } 20\end{array}$ & $\begin{array}{l}\text { Carpets, which were usually spread on the floor, were removed. The } \\
\text { mosque asked believers to wash their hands before prayers and avoid } \\
\text { coming with many people. }\end{array}$ & [60-62] \\
\hline Kagoshima Masjid (Kagoshima Islamic Culture Center) & May 22 & $\begin{array}{l}\text { After the state of emergency was lifted, the mosque was opened only to } \\
\text { people living in the city, requesting them to wear masks and disinfect } \\
\text { their hands. }\end{array}$ & [52] \\
\hline Mohammadi Mosque Hamamatsu & May 25 & $\begin{array}{l}\text { Eid al-Fitr was held, but unlike previous years, people were requested } \\
\text { to pray with approximately a 1-m space between each other and not to } \\
\text { shake hands and hug. }\end{array}$ & [63] \\
\hline Kofu Masjid & June 18 & $\begin{array}{l}\text { The mosque placed marker tapes at } 1 \text {-m intervals at the prayer space to } \\
\text { prevent close contact. It also requested believers to wear masks and } \\
\text { always opened doors and windows for ventilation. }\end{array}$ & [64] \\
\hline Masjid Gifu & July 7 & $\begin{array}{l}\text { In Friday prayers, which resumed in mid-June, the mosque requested } \\
\text { believers to wear masks and maintain a distance of about } 1 \mathrm{~m} \text { between } \\
\text { others. }\end{array}$ & [65] \\
\hline Isesaki Mosque & November 16 & $\begin{array}{l}\text { The mosque continued Friday prayers, encouraging people to wear } \\
\text { masks and disinfect their hands. }\end{array}$ & [58] \\
\hline
\end{tabular}


(2.). 京都大学

H. Kotani et al.

(a)

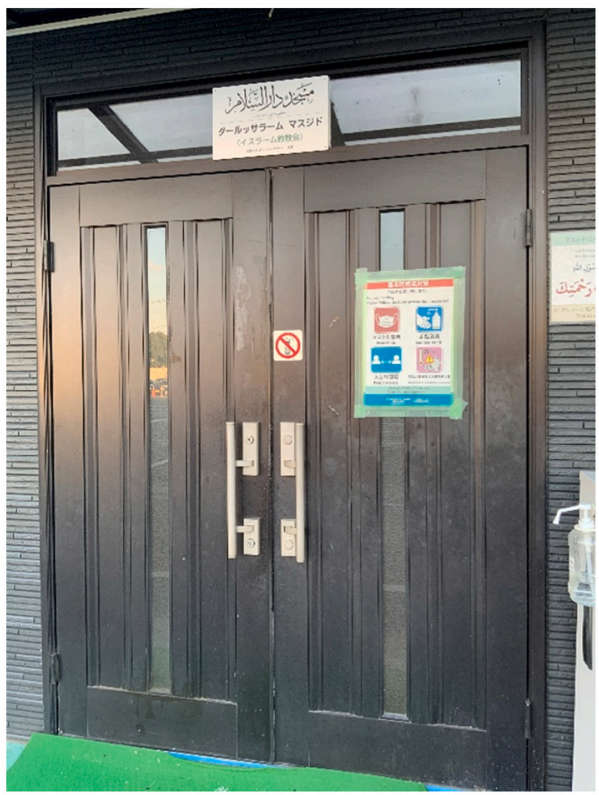

(c)

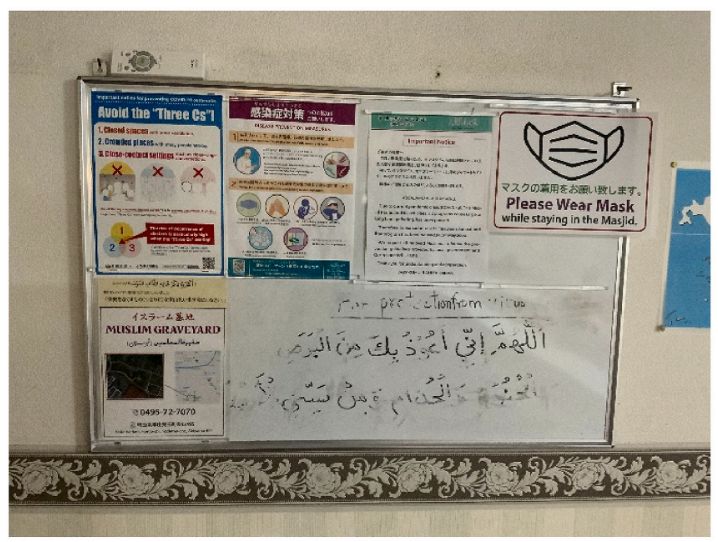

(e)

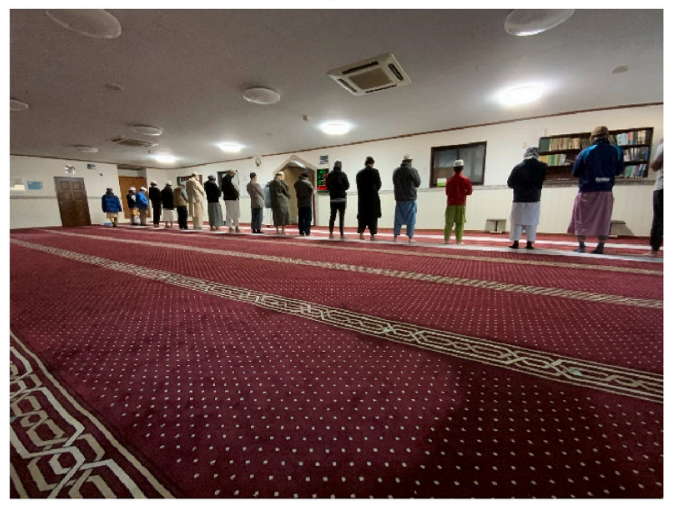

(b)

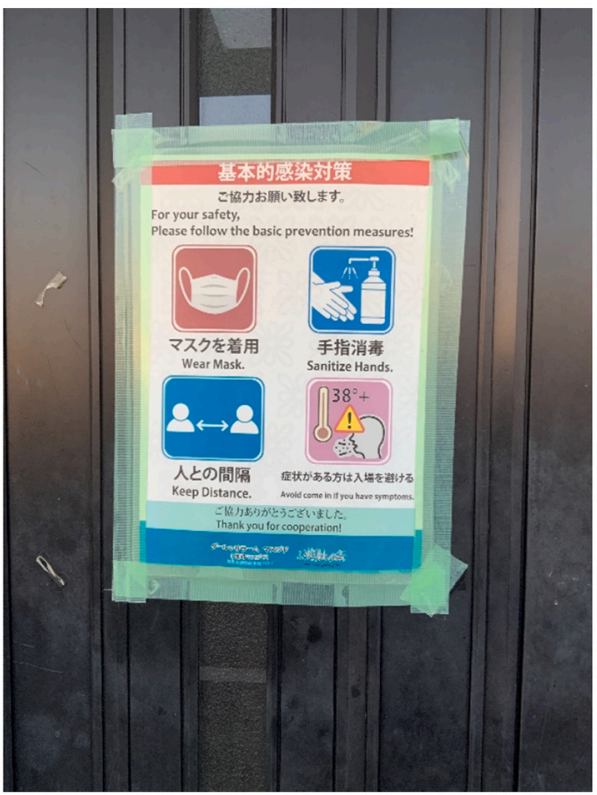

(d)

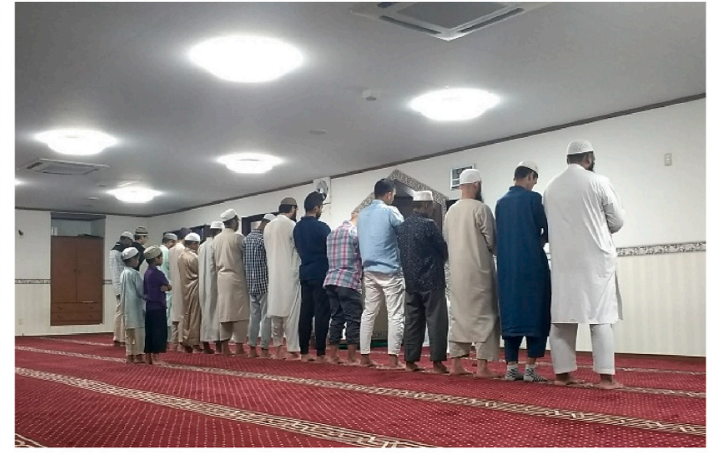

(f)

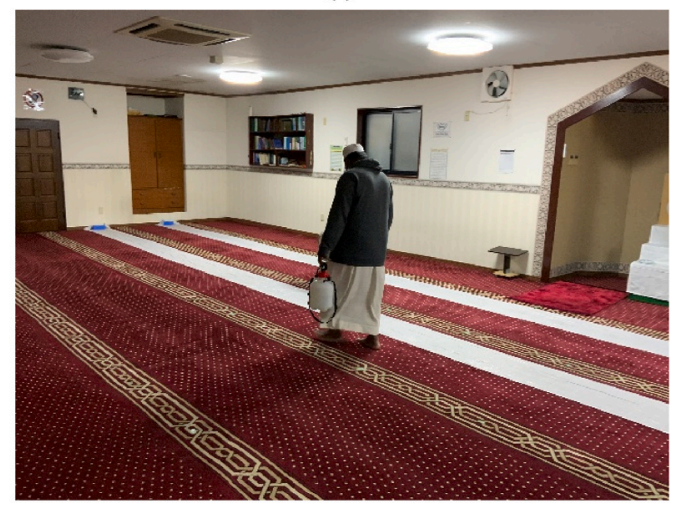

Fig. 4. (a) Hand sanitizer at the entrance of the mosque and a poster promoting infection prevention measures; (b) Detail of the poster; (c) Posters displayed inside the mosque; (d) Prayer before the corona outbreak (photo taken in July 2019); (e) Prayer with maintaining safe distance; (f) Spraying sanitizer after praying. 


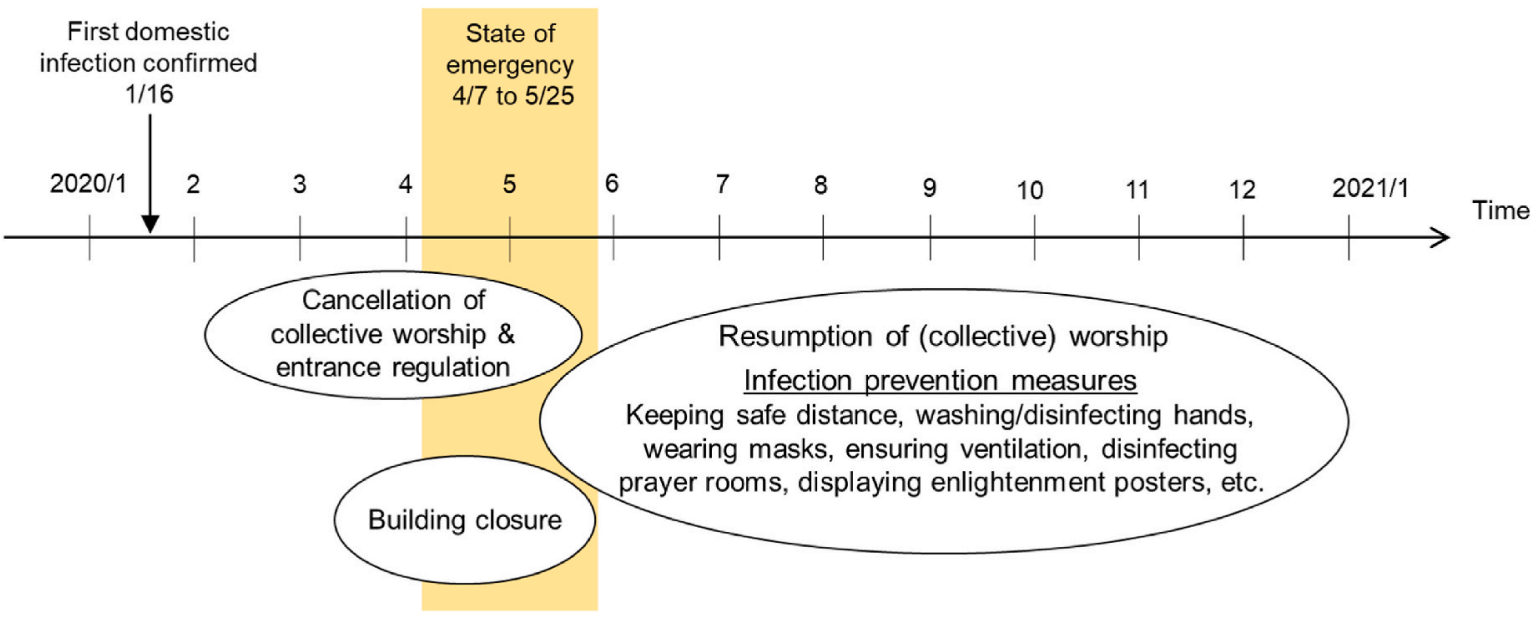

Fig. 5. Overview of the mosques' responses to COVID-19 by the end of December 2020 .

Table 3

Support provided by mosques and its recipients.

\begin{tabular}{ll}
\hline Contents of support & Recipients \\
\hline Donation of masks & Local government \\
Counseling services \& financial support & Japanese people \& foreign Muslims \\
Translation of information & Foreign Muslims \\
Food provision & Foreign Muslims \\
\hline
\end{tabular}

residents, especially foreign Muslims, and other stakeholders, such as the government and healthcare sectors. Government and health institutions are recommended to closely work with mosques as well as other community-based religious institutions to reduce social vulnerability, isolation, and disintegration. Most studies on mosques' responses during the COVID-19 pandemic are from Muslimmajority countries $[69,70,74,75]$, whereas this study focuses on a Muslim-minority country, which helps in presenting a comprehensive international picture of responses of Muslims to the COVID-19 crisis.

This study provided preliminary findings from limited information, and thus several issues remain to be addressed in the future: first, while this study showed examples of infection prevention measures and support provision, it is also important to identify challenges that emerged in their implementation. Such information will contribute to better countermeasures and support. Second, most of the information in this study was from the management side. It is also desirable to understand the perceptions and meanings of prevention measures and support provision for believers or daily visitors. The information obtained from them will further clarify the situation and contribute to a multifaceted evaluation of prevention measures and support provision (For example, as the members of mosques who conducted counseling were generally considered unprofessional, the effectiveness of the support for recipients should be further studied.). Third, this study focused on infection prevention measures. Meanwhile, a response and recovery plan in the case of a positive test is also important, and thus, whether mosques have such a plan and how it should be improved should be discussed in the future. Lastly, this study covered the period up to the end of 2020, but at the time of writing (January 2021), a third wave has already hit Japan, and a state of emergency has been re-declared in parts of the country [76]. Ongoing research into longer-term responses and support is needed.

\section{Funding}

This work was partly supported by the Dai-ichi Life Foundation, the Obayashi Foundation, the Japan Society for the Promotion of Science (KAKENHI Grant No. 18K13845), and ISHIZUE 2021 of Kyoto University Research Development Program. 


\section{Declaration of competing interest}

The authors declare that they have no known competing financial interests or personal relationships that could have appeared to influence the work reported in this paper.

\section{Acknowledgments}

We are deeply grateful to Haroon Qureshi, Mohammad Zaber, and Salim Mazen in Otsuka, Sakaimachi, and Al-Faruq Mosques, respectively, for participating in our interview survey.

\section{References}

[1] B.S.H.M. Fakhruddin, K. Blanchard, D. Ragupathy, Are we there yet? The transition from response to recovery for the COVID-19 pandemic, Prog. Disaster Sci. 7 (2020), 100102.

[2] United Nations, Sendai Framework for Disaster Risk Reduction 2015-2030, 2015.

[3] World Health Organization, Practical Considerations and Recommendations for Religious Leaders and Faith-Based Communities in the Context of COVID-19: Interim Guidance, 2020, 7 April 2020.

[4] World Health Organization, Disaster evacuation shelters in the context of COVID-19. https://apps.who.int/iris/handle/10665/336856, 2020.

[5] N.F. Che Mat, H.A. Edinur, M.K.A. Abdul Razab, S. Safuan, A single mass gathering resulted in massive transmission of COVID-19 infections in Malaysia with further international spread, J. Trav. Med. 27 (2020), https://doi.org/10.1093/jtm/taaa059.

[6] S.A. Quadri, COVID-19 and religious congregations: implications for spread of novel pathogens, Int. J. Infect. Dis. 96 (2020) $219-221$.

[7] P. Vermeer, J. Kregting, Religion and the transmission of COVID-19 in The Netherlands, Religions 11 (2020), 393, https://doi.org/10.3390/rel11080393.

[8] S. Yezli, A. Khan, COVID-19 pandemic: it is time to temporarily close places of worship and to suspend religious gatherings, J. Trav. Med. (2020) 1-2.

[9] T. Oxholm, C. Rivera, K. Schirrman, W.J. Hoverd, New Zealand religious community responses to COVID-19 while under level 4 lockdown, J. Relig. Health (2020) 1-18.

[10] J.C. Gaillard, P. Texier, Religions, natural hazards, and disasters: an introduction, Religion 40 (2010) 81-84.

[11] A.R. Cheema, R. Scheyvens, B. Glavovic, M. Imran, Unnoticed but important: revealing the hidden contribution of community-based religious institution of the mosque in disasters, Nat. Hazards 71 (2014) 2207-2229.

[12] E.P. Joakim, R.S. White, Exploring the impact of religious beliefs, leadership, and networks on response and recovery of disaster-affected populations: a case study from Indonesia, J. Contemp. Relig. 30 (2015) 193-212.

[13] R. Bush, P. Fountain, R.M. Feener, Religious actors in disaster relief: an introduction, Int. J. Mass Emergencies Disasters 33 (2015).

[14] M.A.Z. Mughal, An anthropological perspective on the mosque in Pakistan, Asian Anthropol 14 (2015) $166-181$.

[15] K. Inaba, Religion's response to the earthquake and tsunami in northeastern Japan, Bull. Grad. Sch. Hum. Sci. Osaka Univ. 42 (2016) 43-59.

[16] N. Utaberta, N. Asif, Mosques as emergency shelters in disaster prone regions, Pertanika J. Soc. Scinece Humanit. 25 (2017) $207-216$.

[17] R.A. Sheikhi, H. Seyedin, G. Qanizadeh, K. Jahangiri, Role of religious institutions in disaster risk management: a systematic review, Disaster Med. Public Health Prep. 15 (2021) 239-254, https://doi.org/10.1017/dmp.2019.145.

[18] H. Kotani, M. Tamura, J. Li, E. Yamaji, Potential of mosques to serve as evacuation shelters for foreign Muslims during disasters: a case study in Gunma, Japan, Nat. Hazards 109 (2021) 1407-1423, https://doi.org/10.1007/s11069-021-04883-7.

[19] L. McLaughlin, Japanese religious responses to COVID-19: a preliminary report. https://apjjf.org/2020/9/McLaughlin.html, 2020, 18, 1-23.

[20] P. Cavaliere, Religious institutions in Japan responding to Covid-19-induced risk and uncertainty: some preliminary considerations, J. Relig. Japan. 1 (2020) $1-33$.

[21] J.C. Gaillard, Caste, Ethnicity, Religious Affiliation and Disaster, Routledge Handb. Hazards Disaster Risk Reduction, Routledge, London/New York, 2012, pp. 459-469.

[22] B. Bolin, L.C. Kurtz, Race, class, ethnicity, and disaster vulnerability, in: Handb. Disaster Res., Springer, 2018, pp. 181-203.

[23] Y. Utaka, The Kobe Muslim mosque: experience of "miracles" - 1945 air raid \& 1995 earthquake, in: Sel. Pap. Post-Conference Book, Int. Conf. Arch. Interact. Through Silk Road (IaSU2016 JAPAN), 2017, pp. 193-197.

[24] Y. Utaka, Kobe Muslim Mosque, Toho Shuppansha, 2018 (In Japanese).

[25] Z. Yang, K. Inagaki, H. Yagi, S. Yoshida, S. Sadohara, Emergency evacuation and shelter-seeking behavior of foreign residents in Kumamoto earthquake, J. Disaster Res. 12 (2017) 678-687.

[26] M. Penn, Islam in Japan: adversity and diversity, Harvard Asia Q 10 (2006).

[27] E.A. Nakhleh, K. Sakurai, M. Penn, Islam in Japan: a cause for concern? Asia Pol. 5 (2008) 61-104.

[28] H. Kojima, Variations in demographic characteristics of foreign "Muslim" population in Japan: a preliminary estimation, Jpn. J. Popul. 4 (2006) 115-130.

[29] H. Tanada, Mosques in Japan [Nippon No Mosuku], Yamakawa Shuppansha, 2015 (In Japanese).

[30] H. Tanada, Estimate of Muslim population in the World and Japan, 2018, Waseda J. Hum. Sci. 32 (2019) 253-262 (In Japanese), http://hdl.handle.net/2065/ 00063404.

[31] H. Okai, Muslim Communities and Local Communities: reconsidering "Multicultural Conviviality" through the Activities of Islamic Organizations [Musrimu komyunityi to chiiki shakai-Isuramu dantai no katsudou kara "tabunka kyousei" wo saikou suru], in: N. Takahashi, T. Shirahase, S. Hoshino (Eds.), Relig. Multicult. Conviviality Contemp. Japan Explor. Relatsh. Between Immigrants Local Communities [Gendai Nihon No Shukyo To Tabunka Kyousei-Imin To Chiiki Shakai No Kankeisei Wo Saguru], Akashi Shoten, 2018, pp. 181-203 (In Japanese).

[32] K. Sakurai, Muslim Society in Japan [Nippon No Musurimu Shakai], Chikumashobo, 2003 (In Japanese).

[33] N. Asai, Function of social capital embedded in religious communities at times of disaster: cases of disaster relief activity by a Muslim community and a Soka Gakkai community in Japan, J. Disaster Res. 13 (2018) 1323-1332.

[34] S. Nejima, I. Danismaz, Muslim NGOs and volunteers in Tohoku, Japan, in: S. Nejima (Ed.), NGOs Muslim World Faith Soc. Serv., Routledge, 2015 , pp. 116-123.

[35] Ministry of Health, Labour and Welfare, Outbreak of Pneumonia Associated with the New Coronavirus (1st Case) [Shingata korona uirusu ni kanrensita haien kanja no hassei ni tsuite (1 reime)], 2020 (In Japanese), https://www.mhlw.go.jp/stf/newpage_08906.html.

[36] Ministry of Health, Labour and Welfare, Cabinet Order Establishing Novel Coronavirus Infections as a Designated Infectious Disease [Shingata Korona Uirusu Kansensho Wo Shitei Kansensho Toshite Sadameru Tou No Seirei], 2020 (In Japanese).

[37] National Institute of Infectious Diseases, Field Briefing: Diamond Princess COVID-19 Cases, 2020. https://www.niid.go.jp/niid/en/2019-ncov-e/9407-covid-dpfe-01.html.

[38] H. Nishiura, Backcalculating the incidence of infection with COVID-19 on the Diamond princess, J. Clin. Med. 9 (2020).

[39] Ministry of Health, Labour and Welfare, Basic Policies for Novel Coronavirus Disease Control [Shingata korona uirusu kansensho taisaku no kihon houshin], 2020 (In Japanese), https://www.mhlw.go.jp/content/10900000/000599698.pdf. 
[40] Ministry of Education, Simultaneous Temporary Closure of Elementary, Junior High, Senior High, and Special Support Schools as Countermeasures against the New Coronavirus Infection [Shingata Korona Uirusu Kansensho Taisaku No Tameno Shougakkou, chugakkou], 2020 (In Japanese), https://www.mext.go.jp/ content/202002228-mxt_kouhou01-000004520_1.pdf.

[41] World Health Organization, WHO Director-General's Opening Remarks at the Media Briefing on COVID-19-11 March 2020, 2020. https://www.who.int/ director-general/speeches/detail/who-director-general-s-opening-remarks-at-the-media-briefing-on-covid-19-11-march-2020.

[42] Prime Minister of Japan and his Cabinet, telephone talks between Prime Minister abe and president bach of the international olympic Committee [abe souridaijin to bahha kokusai orimpic iinkai kaicho tono denwa kaidan] (In Japanese), https://www.kantei.go.jp/jp/singi/tokyo2020_suishin_honbu/pdf/ 200324pressrelease.pdf, 2020.

[43] Prime Minister of Japan and His Cabinet, [COVID-19] the Declaration of the Lifting of the State of Emergency in Response to the Novel Coronavirus Disease, 2020. https://japan.kantei.go.jp/ongoingtopics/_00027.html.

[44] M.K. Looi, Covid-19: Japan declares state of emergency as Tokyo cases soar, BMJ 369 (2020), m1447.

[45] M.K. Looi, Covid-19: Japan ends state of emergency but warns of "new normal", BMJ 369 (2020), m2100.

[46] NHK, Special Site: New Coronavirus. State of Emergency Declared for the First Time [Tokusetsu Saito Shingata Korona Uirusu Kinkyu Jitai Sengen 1 Kaime No Jokyo], 2020 (In Japanese), https://www3.nhk.or.jp/news/special/coronavirus/emergency.

[47] NHK, Special Site: New Coronavirus. What about School Reopening? [Tokusetsu Saito Shingata Korona Uirusu Gakkou Saikai Ha Dounaru?], 2020 (In Japanese), https://www3.nhk.or.jp/news/special/coronavirus/school-guideline/.

[48] A. Tashiro, R. Shaw, COVID-19 pandemic response in Japan: what is behind the initial flattening of the curve? Sustainability 12 (2020), 5250.

[49] K. Shimizu, M. Negita, Lessons learned from Japan's response to the first wave of COVID-19: a content analysis, Healthcare 8 (2020), 426, https://oi.org/ 10.3390/healthcare8040426.

[50] The Japan Times, Let's Discuss the Go to Travel Campaign, 2020. https://www.japantimes.co.jp/life/2020/07/21/language/english-lets-go-to-travelcampaign/.

[51] Nikkei Asia, Japan's Suga to Halt Whole Travel Campaign as COVID Surges, 2020. https://asia.nikkei.com/Economy/Japan-s-Suga-to-halt-whole-travelcampaign-as-COVID-surges.

[52] Asahi Shimbun, (Novel Coronavirus) Ramadan. Quiet with Families: Muslims' Fasting Month. Avoiding Gatherings and Praying at Home/Kagoshima Prefecture [(Shingata korona) Ramadan, kazoku de shizuka ni Isuramu kyouto no danjiki tsuki atumari sake, jitaku de/Kagoshima ken], May 22 (2020). (In Japanese).

[53] Asahi Shimbun, (Novel Coronavirus) Prayers Continue at Home and Online as Mosques Closed; Mass Online in Toyama Prefecture [(Shingata korona) Ie de, douga de, inori ha tsuzuku mosuku wo heisa $\cdot$ raibu de misa/Toyama ken], May 14 (2020). (In Japanese).

[54] Asahi Shimbun, Foreign Believers Unable to Gather at Churches and Mosques as Group Worship Is Cancelled (Nagoya) [Syuudan Reihai Nakunari, Todaeta Kouryuu Gaikokujin Sinnjyara, Kyoukai Mosuku Atumarezu (Nagoya)], May 14 (2020). (In Japanese).

[55] Mainichi Newspapers, Novel Coronavirus: in Ramadan, Stay Home and Keep Social Distance as an Islamic Teaching [Shingata Korona: Shingata Korona Ramadan Stay Home Syakai Teki Kyori Ha Isuramu No Oshie], May 12 (2020). (In Japanese).

[56] Yomiuri Shimbun, Ayase City Officers Teach Infection Prevention to Foreigners, Visiting Restaurants and Religious Facilities/Kanagawa Prefecture [Ayase shi kansenyobousaku gaikokokujin ni shidou insyokuten ya syuukyoushisetu houmon=Kanagawa], December 2, 2020 (In Japanese).

[57] Mainichi Newspapers, Osaka Masjid (Osaka City) Experience "Islam" in a Casual Way [Kansaigaku: oosaka masujiddo (oosaka shi) kigaruni "isuramu" wo taiken], December 3 3, 2020 (In Japanese).

[58] Asahi Shimbun, (Press Release) Corona Disaster: Seeking a "Prayer Space" for Christianity, Islam, and Buddhism/Gunma Prefecture [(Kisyahoukoku) Koronaka, "inori no ba" mosaku kirisuto kyou, isuramu kyou, bukkyou/Gunma ken], Nov 16, 2020 (In Japanese).

[59] Yomiuri Shimbun, Player Places Affected by Corona: mass Online and Ventilation during Services... Work Hard to Cope [Inori no ba, korona ga kage, misa tyuushi, reihai ji ni kanki... taiou kenmei], April 13 (2020). (In Japanese).

[60] Yomiuri Shimbun, Support Affected by Corona: Helpdesk Shortage amid a Flood of Calls for Help from Foreigners Unfamiliar with Japan [Shien No Te Ni Korona No Kage Funare Gaikokujin Seikatu Soudan Denwa Sattou Madoguti Tarinu], May 12 (2020). (In Japanese).

[61] Mainichi Newspapers, Novel Coronavirus: Rohingya Pray in Solitude at a Mosque in Gunma [Shingata Korona: Shingata Korona Rohingya, Kodoku No Inori Gunma No Mosuku], May 22 (2020). (In Japanese).

[62] Mainichi Newspapers, Eye: Rohingya Wish for Return to Normal Life [eye: Nichijyou seikatu modotte inoru Rohingya], June 20, 2020 (In Japanese).

[63] Asahi Shimbun, End of Ramadan. Festivals Held Online and in Mosques while Keeping Safe Distance/Shizuoka Prefecture [Ramadan Ake, Maturi Gamen Goshi Kakkoku No Syuukan Syoukai, Mosuku Deha Lankaku Ake/Shizuoka Ken], May 25 (2020). (In Japanese).

[64] Yomiuri Shimbun, New Style of Prayer and Online Sutra Reading/Yamanashi Prefecture [Oinori shinyoushiki ni tegotae reihai, dokkyou onrain de=Yamanashi], June 18, 2020 (In Japanese).

[65] Asahi Shimbun, (Novel Coronavirus) Change in Prayer Style: Refraining from Singing Hymns. Multiple Worship Services with Small Groups/Gifu Prefecture [(Shingata Korona) Inori No Ba Mo, Kawaru Youshiki Sanbika Wo Jisyuku, Bunsann Sanretu Syuukai Ya Reihai ga saikai/Gifu], 2020 (In Japanese), July 7.

[66] Asahi Shimbun, (Shizuoka Report 35) Muslims Deepen Ties in Ramadan as They can't Meet: The Corona Disaster/Shizuoka Prefecture [(Shizuoka ripo-to 35) Aenai ramadan, kizuna fukameru koronaka de musurimu/Shizuoka ken], May 24 (2020). (In Japanese).

[67] Takaoka City Office, Donation of masks (Toyama Muslim Center) [Masuku wo kizo itadakimashita] (In Japanese), https://www.city.takaoka.toyama.jp/joho/ shise/koho/hodo/mottohot/2020mottohot/202005/muslim.html, 2020. (Accessed 16 January 2021).

[68] World Health Organization, Managing the COVID-19 Infodemic: Promoting Healthy Behaviours and Mitigating the Harm from Misinformation and Disinformation, 2020. https://www.who.int/news/item/23-09-2020-managing-the-covid-19-infodemic-promoting-healthy-behaviours-and-mitigating-theharm-from-misinformation-and-disinformation.

[69] S. Yezli, A. Khan, COVID-19 social distancing in the Kingdom of Saudi Arabia: bold measures in the face of political, economic, social and religious challenges, Trav. Med. Infect. Dis. 37 (2020), 101692.

[70] S.G.S. Shah, Doctors in Pakistan denounce opening of mosques for congregational prayers during Ramadan amid the COVID-19 pandemic: Correspondence, Int. J. Surg. 79 (2020) 40-41, https://doi.org/10.1016/j.ijsu.2020.05.006.

[71] K. Koto-Shimada, M. Nishihara, M. Kim, Y. Yamamoto, F. Hirono, T. Sawada, T. Nakasa, Assisting migrants in Japan to navigate the COVID-19 pandemic, J. Int. Health 35 (2020) 97-98 (In Japanese).

[72] United Nations, Transforming Our World: the 2030 Agenda for Sustainable Development, 2015.

[73] K. Inaba, A. Kawabata, Report on a survey on cooperation between local governments and religious institutions and organizations in times of disaster [Jichitai to shukyou shisetsu dantai tono saigaiji kyouryoku ni kansuru chousa houkoku], Relig. Soc. Contrib. 10 (2020) 17-29, https://doi.org/10.18910/75539 (In Japanese).

[74] J. Gee, South East asian Muslims respond to COVID-19 outbreak, Washingt, Rep. Middle East Aff (2020) 48-49. June/July, https://www.wrmea.org/turkey/ other/south-east-asian-muslims-respond-to-covid-19-outbreak.html.

[75] R. Jardine, J. Wright, Z. Samad, Z.A. Bhutta, Analysis of COVID-19 burden, epidemiology and mitigation strategies in Muslim majority countries, East. Mediterr. Health J. 26 (2020), 1173.

[76] M.K. Looi, Covid-19: Japan declares second state of emergency as Asia struggles with virus surge, BMJ 372 (2021), https://doi.org/10.1136/bmj.n141.

[77] N. Smith, There's No Such Thing as a Natural Disaster, Soc. Sci. Res. Counc., 2006. http://blogs.ubc.ca/naturalhazards/files/2016/03/Smith-There,s-No-SuchThing-as-a-Natural-Disaster.pdf. (Accessed 24 November 2021). 
[78] I. Kelman, Disaster by Choice: How Our Actions Turn Natural Hazards into Catastrophes, Oxford University Press, 2020.

[79] Asahi Shimbun, (Novel Coronavirus) A Quiet Ramadan: Muslim International Students and Others in Kyoto/Kyoto Prefecture [(Shingata Korona) Ippen, Shizukana "Ramadan" Ryuugakusei Ra Kyouto No Isuramu Kyouto/Kyouto Fu], May 15 (2020). (In Japanese).

[80] Asahi Shimbun, (Novel Coronavirus) The Pain of Not Being Able to Gather at Prayer Sites: Christianity and Islam [(Shingata Korona) Inori No Ba, Tudoenu Kurusimi Kirisuto Kyou, Isuramu Kyou], May 20 (2020). (In Japanese).

[81] Mainichi Newspapers, Novel Coronavirus: religious Institutions in Japan Refrain from Mass Worship Fearing Infection [Shingata korona: shingata korona syuudan reihai, jisyuku no ugoki kokunai syuukyou shisetu, kansen kenen], April 23 (2020). (In Japanese). 